\title{
Domperidone for Drug-Induced Orthostatic Hypotension-A Review
}

Daniel E. McDonald, M.D.

University of British Columbia, Vancouver, BC, Canada

Raymond W. Lam, M.D., F.R.C.P.(C)

University of British Columbia, Vancouver, BC, Canada

Follow this and additional works at: https://jdc.jefferson.edu/jeffjpsychiatry

Part of the Psychiatry Commons

Let us know how access to this document benefits you

\section{Recommended Citation}

McDonald, M.D., Daniel E. and Lam, M.D., F.R.C.P.(C), Raymond W. (1992) "Domperidone for Drug-Induced Orthostatic Hypotension-A Review," Jefferson Journal of Psychiatry. Vol. 10 : Iss. 1 , Article 5.

DOI: https://doi.org/10.29046/JJP.010.1.002

Available at: https://jdc.jefferson.edu/jeffjpsychiatry/vol10/iss1/5

This Article is brought to you for free and open access by the Jefferson Digital Commons. The Jefferson Digital Commons is a service of Thomas Jefferson University's Center for Teaching and Learning (CTL). The Commons is a showcase for Jefferson books and journals, peer-reviewed scholarly publications, unique historical collections from the University archives, and teaching tools. The Jefferson Digital Commons allows researchers and interested readers anywhere in the world to learn about and keep up to date with Jefferson scholarship. This article has been accepted for inclusion in Jefferson Journal of Psychiatry by an authorized administrator of the Jefferson Digital Commons. For more information, please contact: JeffersonDigitalCommons@jefferson.edu. 


\title{
Domperidone for Drug-Induced Orthostatic Hypotension-A Review
}

\author{
Daniel E. McDonald, M.D. \\ Raymond W. Lam, M.D., F.R.C.P.(C)
}

\begin{abstract}
Drug-induced orthostatic hypotension $(\mathrm{OH})$ is a common side effect of heterocyclic and MAOI antidepressant medications. It usually does not respond to conservative treatment and drug treatments with mineralocorticoids or central dopaminergic antagonists such as metoclopramide have significant long-term side effects that limit their use. Domperidone, a peripherally acting dopaminergic antagonist with few side effects, has been used in a number of small clinical trials to treat $\mathrm{OH}$ of various etiologies. We reviewed 9 studies of domperidone in the treatment of $\mathrm{OH}$. Although limited by small sample sizes and poor design, these studies generally showed successful treatment of $\mathrm{OH}$ by domperidone. Further controlled studies of domperidone for antidepressantinduced $\mathrm{OH}$ in relevant patient samples are warranted.
\end{abstract}

\section{INTRODUCTION}

Drug-induced orthostatic hypotension $(\mathrm{OH})$, a common side effect of heterocyclic and monoamine oxidase inhibitor (MAOI) antidepressants, is often encountered in clinical practice $(1,2)$. One study found that severe symptomatic $\mathrm{OH}$ (repeated fainting or falling) occurred in $9 \%$ of patients on imipramine, $11 \%$ of patients on phenelzine, and $17 \%$ of patients on tranylcypromine (3). The adverse consequences of drug-induced $\mathrm{OH}$ are evident, particularly for the elderly where falls can result in broken hips. Newer antidepressants such as serotonergic reuptake inhibitors do not cause significant blood pressure changes. However, some patients may need treatment with heterocyclics and MAOIs because of refractory depression or specificity of response. For example, patients may be preferentially responsive to MAOIs for anergic bipolar depressions (4) or atypical depressions (5). Thus, for some patients it is important to treat side effects such as $\mathrm{OH}$ rather than to switch to another antidepressant.

Drug-induced $\mathrm{OH}$, however, is often difficult to manage (6). Conservative treatments such as patient education, vascular stockings, increased salt and increased fluid intake are usually insufficient. Fludrocortisone, a mineralocorticoid volume expander, has been the most commonly used pharmacologic agent for antidepressant-induced $\mathrm{OH}$. Fludrocortisone is effective in treating $\mathrm{OH}$, but carries significant side effects such as resting hypertension, hypokalemia and congestive heart failure as well as other possible corticosteroid effects. Dopaminergic antago- 
nists such as metaclopramide have been extensively used as a treatment for $\mathrm{OH}$ in Parkinsons disease and autonomic neuropathies, and have also been successful in the treatment of MAOI-induced OH (7). Like other phenothiazine drugs, metaclopramide acts centrally and also has potentially significant side effects including extrapyramidal symptoms, hyperprolactinemia and tardive dyskinesia.

Domperidone (tradename: Motilium) is a peripheral dopamine antagonist that does not cross the blood brain barrier, has no central dopaminergic activity, and therefore is devoid of these risks (8). Recently domperidone has been successfully used in small clinical trials for $\mathrm{OH}$ secondary to Parkinsons disease, diabetic autonomic neuropathy, central neurological injury and drug-induced $\mathrm{OH}$. This article will review the literature addressing domperidone as a treatment of $\mathrm{OH}$. Our literature search revealed only nine articles focusing on domperidone and orthostatic hypotension.

Domperidone is mainly used as an upper gastrointestinal motility agent (9). Like metoclopramide, it has antiemetic and gastroprokinetic properties. Domperidone is generally well tolerated and has a low incidence of side effects, predominantly dry mouth $(1.9 \%)$, headache $(1.2 \%)$, abdominal cramps $(<1 \%)$, and diarrhea $(<1 \%)$ (10). Although it has no central effects it can raise prolactin levels (10). Its usual dosage range is 30 to $60 \mathrm{mg}$ daily for upper gastrointestinal motility disorders.

Because of its antiemetic properties, domperidone was used to treat the nausea and emesis associated with dopaminergic agents in the treatment of Parkinsons disease. The dopamine agonist apomorphine also causes $\mathrm{OH}$, likely mediated through peripheral, rather than central, dopaminergic mechanisms (11). A doubleblind study (12) in 4 drug-free patients with Parkinsons disease found the acute administration of domperidone (100 ug/ $\mathrm{kg} \mathrm{IM})$, but not saline, prevented the nausea, sedation, and arterial hypotension seen after apomorphine injection (20 ug/kg IM). Pollack et al. (13) also studied both the acute and chronic blood pressure effects of domperidone in two separate studies of patients with Parkinsonism. In a single-blind study involving 10 patients, domperidone (12 mg IM) or placebo was administered, followed by $1 \mathrm{mg}$ of apomorphine. In the placebo condition, apomorphine significantly lowered supine and erect blood pressures. The domperidone significantly increased supine diastolic blood pressure, erect systolic and diastolic blood pressure, and blocked the hypotensive effects of apomorphine. The second study examined the longer-term blood pressure effects of domperidone in 16 patients with idiopathic Parkinsons disease chronically treated with a variety of dopaminergic drugs. Five of these patients had occasional asymptomatic $\mathrm{OH}$. Patients were given either placebo or domperidone for one week in a double blind cross-over design. In these patients domperidone slightly, but significantly, raised supine systolic blood pressure and erect systolic and diastolic blood pressure over the one-week period.

These encouraging results were not supported in other studies with domperidone and bromocriptine. Agid et al. found that domperidone (60 mg/day) blocked bromocriptine-induced nausea and vomiting and allowed for rapid attainment of high therapeutic doses of bromocriptine (14). There was, however, no protection against hypotension in this placebo-controlled study. All four patients who had 
orthostatic hypotension (out of a total of 17 subjects) were in the domperidone group. Two further reports by the same group found that larger doses of domperidone ( 150 $\mathrm{mg} /$ day) had no effect on blood pressure nor the occurrence of orthostatic hypotension in 20 patients treated with high-dose bromocriptine $(15,16)$, although these two reports seem to consist of the same patient sample. This discrepancy in results with bromocriptine and apomorphine suggests that bromocriptine-induced postural hypotension involves central mechanisms rather than peripheral mechanisms.

Although these studies of domperidone and dopamine agonists have shown mixed results on blood pressure effects, clinical studies of domperidone in treating $\mathrm{OH}$ have generally been favorable. One report found that domperidone $(60 \mathrm{mg} /$ day $)$ was effective for treating the $\mathrm{OH}$ of 3 hypertensive patients with concurrent $\mathrm{OH}$ from several etiologies (17). Montastruc et al. (18) looked at domperidone's effects in 8 patients with "severe symptomatic orthostatic hypotension" of various etiologies (3 patients had central neurological injury, 2 cases had idiopathic $\mathrm{OH}$, and 3 patients had drug-induced $\mathrm{OH}$ due to clomipramine or antimitotic medication). After 5 days of treatment with domperidone $\mathrm{OH}$ improved and symptoms disappeared in all cases. After $5.0 \pm 1.4$ months mean follow-up the orthostatic drop was significantly reduced from $53.1 \pm 4 \mathrm{mmHg}$ before treatment to $25.0 \pm 9.5 \mathrm{mmHg}$ after domperidone. Domperidone has also been effective in treating symptomatic $\mathrm{OH}$ in diabetic autonomic neuropathy (19). Lopes de Faria et al. (20) studied 9 patients with diabetic autonomic neuropathy and showed that oral domperidone $30 \mathrm{mg} /$ day for 3 days significantly decreased the orthostatic drop in blood pressure. Six of these patients maintained their improvement after a 6-month follow-up.

\section{DISCUSSION}

The mechanism of action of domperidone on blood pressure remains poorly understood. Peripherally acting dopamine may have vasodilating and naturietic effects, and excessive dopamine release upon standing has been described in patients with $\mathrm{OH}$ (21). Metoclopramide is hypothesized to inhibit these effects and increase plasma levels of aldosterone and free epinephrine (22). Domperidone's peripheral dopaminergic blockade may have similar effects. Domperidone is also a specific antagonist of D2 presynaptic dopamine receptors (23). Since norepinephrine release is inhibited by dopaminergic activity on D2 receptors, domperidone's effect on $\mathrm{OH}$ may be mediated through enhancement of peripheral noradrenergic activity. Preliminary studies, however, have not found significant increases in plasma renin activity, aldosterone, responsiveness to angiotensin II, nor urinary catecholamines that might explain the postural blood pressure changes following domperidone (20).

In summary, this review indicates that domperidone was effective in the treatment of symptomatic $\mathrm{OH}$ due to varied causes including diabetic neuropathy, central neurological injury, Parkinsonism and some drug-induced $\mathrm{OH}$. However, these studies are limited by small sample sizes, open clinical designs, and the inclusion of multiple etiologies for $\mathrm{OH}$. None compared domperidone to other effective treatments for $\mathrm{OH}$. The mechanism for domperidone's action on blood pressure is 
unknown, so domperidone may be effective only for certain etiologies of OH. Only one patient in these studies had antidepressant-induced $\mathrm{OH}$. However, heterocyclic and MAOI antidepressants continue to be essential tools in our psychopharmacologic armamentarium, despite their hypotensive side effects. For some patients with antidepressant-induced $\mathrm{OH}$, particularly those who did not respond to antidepressants that do not have $\mathrm{OH}$ as a side effect, it will be clinically advantageous to treat the $\mathrm{OH}$ rather than switching drugs. Because domperidone is a well-tolerated medication with few side effects, it will be worthwhile to determine in controlled studies whether it is an effective treatment for antidepressant-induced $\mathrm{OH}$ in these patients. Since $\mathrm{OH}$ can be symptomatic or asymptomatic, transient or continuous, future clinical studies should operationalize the definition and measurement of $\mathrm{OH}$ in order to determine the clinical versus statistical significance of treatments.

\section{REFERENCES}

1. Remick RA, Froese C, Keller FD: Common side effects associated with monoamine oxidase inhibitors. Prog Neuropsychopharmacol Biol Psychiatry 13:497-504, 1989

2. Glassman AH, Bigger T: Cardiovascular effects of therapeutic doses of tricyclic antidepressants: a review. Arch Gen Psychiatry 38:815-820, 1981

3. Rabkin JG, Quitkin FM, McGrath P, et al: Adverse reactions to monoamine oxidase inhibitors. Part II. Treatment correlates and clinical management. J Clin Psychopharmacol 5:2-9, 1985

4. Thase ME, Mallinger AG, McKnight D, Himmelhoch JM: Treatment of imipramineresistant recurrent depression, IV: a double-blind crossover study of tranylcypromine for anergic bipolar depression. Am J Psychiatry 149:195-198, 1992

5. Liebowitz MR, Quitkin FM, Stewart JW, et al: Antidepressant specificity in atypical depression. Arch Gen Psychiatry 45:129-137, 1988

6. Cockhill L, Remick RA: Blood pressure effects of monoamine oxidase inhibitors-the highs and lows. Can J Psychiatry 32:803-808, 1987

7. Patterson JF: Metoclopramide therapy of MAOI orthostatic hypotension (letter). J Clin Psychopharmacol 7:112-3, 1987

8. Laduron PM, Leysen JE: Domperidone, a specific in vitro dopamine antagonist, devoid of in vivo central dopaminergic activity. Biochem Pharmacol 28:2161-2165, 1979

9. Champion MC, Hartnett M, Yen M: Domperidone, a new dopamine antagonist. CMAJ 135:457-461, 1986

10. Product Monograph-Motilium (domperidone). Janssen Pharmaceutica Inc., 1985

11. Bogaert MG, Buylaert WA, Willems JL: Hypotension produced by intravenous apomorphine in the anaesthetized dog is not centrally mediated. Br J Pharmac 63:481-484, 1978

12. Corsini GU, Del Zompo M, Gessa GL, Margoni H: Therapeutic efficacy of apomorphine combined with an extracerebral inhibitor of dopamine receptors in Parkinsons disease. Lancet 1:954-6, 1979

13. Pollack P, Mallaret M, Gais JM, Hommel M, Perret J: Blood pressure effects of apomorphine and domperidone in Parkinsonism. Adv Neurology 45:263-6, 1987

14. Agid Y, Pollack P, Bonnet AM, Signoret JL, Lhermitte F: Bromocriptine associated with a peripheral dopamine blocking agent in treatment of Parkinsons disease. Lancet 1:570-2, 1979 
15. Quinn N, Illas A, Lhermitte F, Agid Y: Bromocriptine and domperidone in the treatment of Parkinsons disease. Neurology 31:662-7, 1981

16. Quinn N, Illas A, Lhermitte F, Agid Y: Bromocriptine in Parkinsons disease: a study of cardiovascular effects. J Neurol Neurosurg Psychiatry 44:426-9, 1981

17. Chamontin B, Montastruc JL, Salvador MJ: Hypertension with orthostatic hypostension: interest of verapamil. J Cardiovasc Pharmacol 10 Suppl 10:S114-6, 1987

18. Montastruc JL, Chamontin B, Senard JM, Rascol A: Domperidone in the management of orthostatic hypotension. Clin Neuropharmacol 8:191-2, 1985

19. Destee A, Leys D, Delisse B, Warot P: Orthostatic hypotension due to diabetic autonomic neuropathy? Treatment with domperidone (letter). Arch Neurol 44:11, 1987

20. Lopes de Faria SR, Zanella MT, Andriolo A, Ribeiro AB, Chacra AR: Peripheral dopaminergic blockade for the treatment of diabetic orthostatic hypotension. Clin Pharmacol Ther 44:670-4, 1988

21. Kuchel O, Buu NT, Hamet P, Larochelle P, Gutkowska J: Orthostatic hypotension: a posture-induced hyperdopaminergic state. Am J Med Sci 289:3-11, 1985

22. Kuchel O, Buu NT, Gutkowska J, Genest J: Treatment of severe orthostatic hypotension by metoclopramide. Ann Intern Med 93:841-843, 1980

23. Kohli JD, Glock D, Goldberg LI: Selective DA2 versus DA1 antagonist activity of domperidone in the periphery. Eur J Pharmacol 89:137-141, 1983 